\title{
7. Technical Studies on the White-glazed Sherds Excavated from the Archaeological Site, A'Ali in Bahrain
}

\author{
By Tatsuo SASAKI, ${ }^{* 1)}$ Tetsuo UChIDA, ${ }^{* 2)}$ Takayasu KoEzUKA, ${ }^{* 3)}$ \\ Shuji NinOmiYA, ${ }^{* 4)}$ Masumi OsAWA, ${ }^{* 4)}$ and \\ Kazuo YAMASAKI, M. J. A. ${ }^{* 5}$
}

(Communicated March 12, 1993)

\begin{abstract}
Some Islamic white-glazed sherds excavated from an archaeological site of the 9th century, A'Ali in Bahrain on the coast of Persian Gulf were technically studied to find their characteristics and provenances. The white glazes of some sherds contain fairly large amounts of tin and lead, while others do not. This fact has been hitherto unknown in detail. The results of chemical analyses and X-ray diffraction of glazes and fabrics (body clays), and trace element contents of fabrics determined by instrumental neutron activation analysis are presented, and their provenances are discussed.
\end{abstract}

Key words: White glaze; early Islamic ceramics; Bahrain; chemical analysis; X-ray diffraction; instrumental neutron activation analysis.

Introduction. Some Islamic white-glazed sherds excavated from an archaeological site, A'Ali of the 9th to 11th centuries in Bahrain on the coast of the Persian Gulf were technically studied to find their characteristics and provenances. This site has been excavated by the Japanese excavation team under the direction of Sasaki. ${ }^{1)}$

Archaeological site. A'Ali is a ruined village in the central region of Bahrain Island. The main date of A'Ali is the 9th century. A large number of earthenwares and glazed Islamic wares were found with some Chinese white porcelain and Changsha wares. Colours of the glazed Islamic wares are blue-green, white, brown, yellow and polychrome. Blue-green glaze is the majority, white glaze being the next. The main fabrics of blue-green and white wares are creamy yellow. These two types of wares were mainly made in Mesopotamia in the 9th century.

Samples for investigation. Here only Islamic ceramic sherds with white glazes are studied and these samples are listed in Table I.

Methods of investigation. First the glazes and the fabrics (body clays) of the sherds were studied by X-ray fluorescence analysis, and by X-ray diffraction. Then the glazes and fabrics were chemically analyzed by using inductively coupled plasma atomic emission spectroscopy (abbreviated as ICP). Further the body clays were studied for their trace element contents by the instrumental neutron activation analysis (abbreviated as INAA) using the nuclear reactor (TRIGA Mark II) of the Rikkyo University in Tokyo.

Results and discussion. (A) Chemical compositions of white glazes and body clays. The results of chemical analyses by ICP are given in Tables II and IV. Compounds found in the white glazes by X-ray diffraction are given in Table III.

\footnotetext{
*1) Department of Archaeology, Kanazawa University, Kanazawa, Japan.

*2) Nagoya Institute of Technology, Nagoya, Japan.

*3) Conservation Laboratory, Nara National Research Institute for Cultural Property, Nara,

*4) Tokyo Gakugei University, Koganei, Tokyo, Japan.

*5) Professor Emeritus, Nagoya University, Nagoya, Japan.
} Japan. 


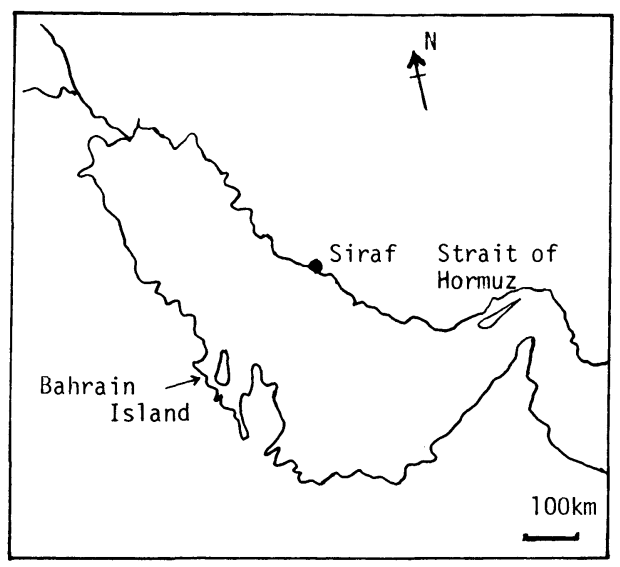

Fig. 1. Persian gulf.

Table I. White-glazed sherds studied

\begin{tabular}{|c|c|c|}
\hline Sample & Type of ware & Produced place \\
\hline SAA-1 & White-glazed bowl with creamy yellow fabric & Mesopotamia \\
\hline SAA-5 & $\begin{array}{l}\text { Blue-green-glazed (outside), and white-glazed (inside) } \\
\text { large jar with yellowish green fabric }\end{array}$ & Mesopotamia \\
\hline SAA-6 & $\begin{array}{l}\text { Blue-green-glazed (outside), and white-glazed (inside) } \\
\text { large jar with yellow fabric }\end{array}$ & Mesopotamia \\
\hline SAA-8 & $\begin{array}{l}\text { White-glazed bowl with a pattern of palm leaves in } \\
\text { cobalt blue. Creamy yellow fabric }\end{array}$ & Mesopotamia \\
\hline SAA-10 & Rim of a white-glazed bowl with creamy yellow fabric & Mesopotamia \\
\hline SAA-11 & White-glazed bowl with creamy yellow fabric & Mesopotamia \\
\hline SAA-12 & White-glazed bowl with coarse brownish fabric & Mesopotamia? \\
\hline SAA-13 & $\begin{array}{l}\text { Base of a white-glazed jar painted in cobalt blue and } \\
\text { copper green with creamy yellow fabric }\end{array}$ & Mesopotamia \\
\hline
\end{tabular}

Table II. Chemical compositions (\%) of white glazes

\begin{tabular}{lcccccccc}
\hline Component & $\begin{array}{c}\mathrm{SAA} \\
-1 \mathrm{G}\end{array}$ & $\begin{array}{c}\mathrm{SAA} \\
-5 \mathrm{G}\end{array}$ & $\begin{array}{c}\mathrm{SAA} \\
-6 \mathrm{G}\end{array}$ & $\begin{array}{c}\mathrm{SAA} \\
-8 \mathrm{G}\end{array}$ & $\begin{array}{c}\mathrm{SAA} \\
-10 \mathrm{G}\end{array}$ & $\begin{array}{c}\mathrm{SAA} \\
-11 \mathrm{G}\end{array}$ & $\begin{array}{c}\mathrm{SAA} \\
-12 \mathrm{G}\end{array}$ & $\begin{array}{c}\mathrm{SAA} \\
-13 \mathrm{G}\end{array}$ \\
\hline $\mathrm{Al}_{2} \mathrm{O}_{3}$ & 4.81 & - & - & 4.58 & - & - & - & - \\
$\mathrm{Fe}_{2} \mathrm{O}_{3}$ & 1.71 & - & - & 1.80 & - & - & - & - \\
$\mathrm{CaO}$ & 6.09 & - & - & 2.17 & - & - & - & - \\
$\mathrm{MgO}$ & 2.70 & - & - & 2.07 & - & - & - & - \\
$\mathrm{Na}_{2} \mathrm{O}$ & 1.79 & - & - & 1.20 & - & - & - & - \\
$\mathrm{K}_{2} \mathrm{O}$ & 1.83 & - & - & 1.97 & - & - & - & - \\
$\mathrm{PbO}^{\mathrm{SnO}}$ & 1.70 & 0.05 & 0.03 & 0.03 & 0.003 & 0.22 & 0.61 & 0.01 \\
$\mathrm{Sn}_{2}$ & 9.00 & 0.1 & 0.1 & 0.75 & 0.17 & 4.6 & 6.5 & 0.69 \\
\hline
\end{tabular}

Silica was not determined due to minute amounts of samples.

The data in Table II show that some of the white glazes contain fairly large amounts of tin and lead, which are the cause of opacity of these glazes. The glazes such as SAA-5G, SAA-6G, SAA-10G and SAA-13G are not tin glazes, because tin and lead found in them 
seem to be contaminants of the raw materials, and are not intentionally added. It is to be noted that the small amounts of tin in the galzes such as SAA-5G, 6G, 10G and 13G are not detected by X-ray diffraction, and that chemical analysis should be used for its detection in the glazes. The opaque white colours of these sherds are due to quartz crystals insoluble in the glazes (cf. Table III).

Table IV shows that the body clays of some sherds are rich in iron, calcium and magnesium. These data agree with the mineral compositions revealed by $\mathrm{X}$-ray diffraction that quartz, diopside $\left[\mathrm{CaMgSi}_{2} \mathrm{O}_{6}\right]$ and augite $\left[\mathrm{Ca}(\mathrm{Mg}, \mathrm{Fe}) \mathrm{Si}_{2} \mathrm{O}_{6}\right]$ are much contained in the fabrics (body clays) of sherds, SAA-1 and SAA- 8 .

In 1979 Whitehouse ${ }^{2)}$ reported that although some Islamic white-glazed potteries had been described as tin glazes, examination of 13 sherds from Siraf in Iran by X-ray diffraction and other techniques failed to reveal the presence of tin. He has not published the detailed results yet. Therefore, our results shown above seem to give the first detailed information on this important problem.

(B) Trace element contents of body clays. To find the provenance of these two kinds of white-glazed potteries with and without tin and lead, instrumental neutron activation

Table III. Minerals and compounds present in the glazes

\begin{tabular}{lcccccccc}
\hline $\begin{array}{l}\text { Minerals } \\
\text { and compd. }\end{array}$ & SAA & SAA & SAA & SAA & SAA & SAA & SAA & SAA \\
& $-1 G$ & $-5 G$ & $-6 G$ & $-8 G$ & $-10 \mathrm{G}$ & $-11 G$ & $-12 \mathrm{G}$ & $-13 \mathrm{G}$ \\
\hline quartz & + & + & + & + & + & + & + & + \\
crist & - & - & - & + & + & + & + & + \\
anorth & - & + & + & - & - & - & - & - \\
cass & + & - & - & - & - & + & + & - \\
\hline
\end{tabular}

crist: cristobalite; anorth: anorthite; cass: tin dioxide (cassiterite), $\mathrm{SnO}_{2}$.

Table IV. Chemical compositions (\%) of fabrics (body clays)

\begin{tabular}{lcc}
\hline Component & ${\mathrm{SAA}-1 \mathrm{~B}^{*}}^{*}$ & SAA-8B* \\
\hline $\mathrm{SiO}_{2}$ & 43.3 & 46.7 \\
$\mathrm{Al}_{2} \mathrm{O}_{3}$ & 13.5 & 13.2 \\
$\mathrm{Fe}_{2} \mathrm{O}_{3}$ & 7.30 & 7.32 \\
$\mathrm{CaO}$ & 17.0 & 17.6 \\
$\mathrm{MgO}$ & 8.29 & 8.08 \\
$\mathrm{Na}_{2} \mathrm{O}$ & 2.06 & 2.08 \\
$\mathrm{~K}_{2} \mathrm{O}$ & 1.91 & 1.52 \\
\hline
\end{tabular}

*B means body clays (fabrics).

Table V. Trace element contents of body clays determined by INAA (ppm except for $\mathrm{Na}$ and $\mathrm{Fe}$ expressed in \%)

\begin{tabular}{lcccccccccccc}
\hline Sample & $\mathrm{Na}$ & $\mathrm{Fe}$ & $\mathrm{Rb}$ & $\mathrm{Cs}$ & $\mathrm{La}$ & $\mathrm{Ce}$ & $\mathrm{Sm}$ & $\mathrm{Eu}$ & $\mathrm{Lu}$ & $\mathrm{Th}$ & $\mathrm{Hf}$ & $\mathrm{Sc}$ \\
\hline SAA-1B & 1.37 & 4.93 & 40 & 1.1 & 26 & 41 & 4.8 & 1.0 & 0.4 & 6.7 & 4.0 & 20 \\
SAA-5B & 1.68 & 4.55 & 60 & 1.9 & 23 & 34 & 4.4 & 1.3 & 0.3 & 6.4 & 3.4 & 19 \\
SAA-6B & 1.50 & 4.58 & 70 & 1.5 & 24 & 39 & 4.4 & 1.3 & 0.3 & 5.9 & 3.2 & 19 \\
\hline
\end{tabular}

Other sherds, SAA-8B - SAA-13B are now under investigation. 
analysis (INAA) of the body clays of some sherds was carried out. The trace element contents found are given in Table V.

The above results in Table $\mathrm{V}$ show that the contents of trace elements are almost the same for the samples SAA-1B, SAA-5B, and SAA-6B, indicating the same locality of production presumed in archaeological context. To find the provenance of the sherds studied here comparison with the clays or the sherds of known locality is required. The characteristics of other sherds with different glazes are now under investigation.

Acknowledgements. One of the authors (K. Y.) is grateful for the research grant of the Japan Academy.

\section{References}

1) Sasaki, T.: Proceedings of the Seminar for Arabian Studies, vol. 20, pp. 111-129 (1990).

2) Whitehouse, D.: Annali Istituto Orientale di Napoli, N. S., 39, 45-61 (1979). 